\title{
Unsettling the boundaries between forced and voluntary migration
}

Document Version

Accepted author manuscript

Link to publication record in Manchester Research Explorer

\section{Citation for published version (APA):}

Bakewell, O. (2021). Unsettling the boundaries between forced and voluntary migration. In E. Carmel, K. Lenner, \& R. Paul (Eds.), Handbook on the Politics and Governance of Migration (pp. 124-136). Edward Elgar Publishing Ltd.

\section{Published in:}

Handbook on the Politics and Governance of Migration

\section{Citing this paper}

Please note that where the full-text provided on Manchester Research Explorer is the Author Accepted Manuscript or Proof version this may differ from the final Published version. If citing, it is advised that you check and use the publisher's definitive version.

\section{General rights}

Copyright and moral rights for the publications made accessible in the Research Explorer are retained by the authors and/or other copyright owners and it is a condition of accessing publications that users recognise and abide by the legal requirements associated with these rights.

\section{Takedown policy}

If you believe that this document breaches copyright please refer to the University of Manchester's Takedown Procedures [http://man.ac.uk/04Y6Bo] or contact uml.scholarlycommunications@manchester.ac.uk providing relevant details, so we can investigate your claim.

\section{OPEN ACCESS}




\title{
Unsettling the boundaries between forced and voluntary migration
}

Oliver Bakewell

February 2021

This is a draft chapter. The final version is available in the Handbook on the Politics and Governance of Migration edited by Emma Carmel, Katharina Lenner \& Regine Paul, published in 2021, Edward Elgar Publishing Ltd.

https://doi.org/10.4337/9781788117234.00017

The material cannot be used for any other purpose without further permission of the publisher, and is for private use only.

\begin{abstract}
This chapter critically examines the divide between forced and voluntary migration, exploring the relationship between the formal definitions elaborated in policy and legal frameworks, the academic approaches and the way the terms are used in everyday public discussion. It argues that the boundaries between forced and voluntary migration are inherently blurred and questions their analytical value. Nonetheless, when it comes to policy and practice, lines are routinely drawn to separate forced from voluntary migrants, with lifechanging, sometimes life-threatening consequences for individual migrants and their families. The chapter focuses on three broad ways in which categorisation as forced or voluntary migration shapes outcomes for migrants: their access to basic rights and resources; the social and political attitudes of the people among whom they settle; and, their social trajectory that casts them as potential future citizens or marks them out as strangers for life.
\end{abstract}

Keywords

categories, migration, refugees, protection, agency 


\section{Introduction}

There is little doubt that migrants' experiences of leaving their homes and travelling to settle in a new place will be profoundly affected by the extent to which they are acting as free agents, with the capacity to decide when they leave, where they go and how long they stay. At one extreme, we see members of the wealthy, well-educated and globally connected elite who can relocate from job to job across the world. These are the archetypal voluntary migrants, free to settle where they choose. At the other extreme, there are those expelled from their countries at gunpoint and forced to seek asylum in another country. Those fleeing under such conditions are the archetypal forced migrants, who have no choice about their fate. For the vast majority of people moving across the world, their migration experience is unlikely to match either archetype. Moreover, in practice, the attempts to draw boundaries between forced and voluntary migration produce somewhat arbitrary and inconsistent outcomes.

Nonetheless, the distinction between them permeates academic, policy and popular discourse. In many contexts, how the lines are drawn is critically important. It may mark the difference between being allowed to stay in a country or facing deportation to one's place of origin. It may shape the way people are received in the society to which they move and their prospects of ever returning to their place of origin. However, as I will show, there is no uniform relationship between the 'type' of migration and particular outcomes. Depending on the context, forced and voluntary migrants may be seen very differently and face widely varying policies. Refugees may be (relatively) welcome where economic migrants are seen as threat; in another setting, the opposite may hold. This makes it dangerous to rely broad generalisations, especially unqualified claims about forced or voluntary migrants across the world.

In this chapter, I look more closely at these concepts of forced and voluntary migration, exploring the relationship between the formal definitions elaborated in policy and legal frameworks, the academic approaches and the way the terms are used in everyday public discussion. While these terms forced and voluntary migration often appear to be selfexplanatory, when one prods them to try and find their core, they prove to be somewhat opaque. We can ask what counts as forced migration? When can we say migration is voluntary? As I will show in the first section, to some extent the responses depend on who is doing the asking, when they ask and in what conditions.

These definitions matter as they mark out categories of people and can have huge implications for their lives. Hence, the second section examines the significance of the distinction between forced and voluntary migration. Recognising its importance in terms of policy and the arbitrary impact on people's lives, the third section argues that we should be challenging the 'taken for granted' significance of the distinction. Drawing on the idea of labelling, it argues that describing either people's movement as forced or voluntary, or the 
people themselves as forced or voluntary migrants can trap them in a category that belies their situation (especially with the passage of time) and may preclude potentially productive approaches that could improve their lives.

\section{Delimiting forced and voluntary migration}

What counts as voluntary and forced when it comes to migration? There is no straightforward answer. The person fleeing from their home in the face of threats of violence, leaving all their possessions behind is likely to be identified as a refugee.

Depending where they are given asylum, they may in due course obtain a new citizenship. Nonetheless, if we think about their migration, we can say it was forced. However, we may no longer be talking of them as a forced migrant as they are simply citizens. If they choose to use this new citizenship to move elsewhere, this now looks like voluntary migration. Or what happens when a refugee gains asylum in one place and decides to move on to another in search of better, perhaps safer, living conditions? This makes things less clear; this secondary movement has taken place as a result of the 'free' decision of the refugee. Their trajectory is no longer one of only forced migration. Hence, whether migration is seen as forced or voluntary will vary depending on which part of their overall movement is considered and at what time the assessment is made (on the significance of time for migration governance, see Griffiths, Chapter 26). In many cases, we can see one person as both a forced and voluntary migrant at the same time.

We must also call into question the idea of voluntary migration. If someone moves to escape desperate living conditions in the hope of finding a better income elsewhere, to what extent is this voluntary? It is not clear where the line should be drawn. The graduate who has trained for years but has no prospect of finding a job using her skills in her country of origin may feel she has no choice but to emigrate in search of a more fulfilling role. She moves in search of a better quality of life, albeit moving from one position of privilege perhaps to another. Is this voluntary?

Such reflections, along with abundant empirical examples (Aidani 2010, Bakewell 2011, Crawley and Skleparis 2018, Long 2013) show that the boundaries between forced and voluntary migration are inherently blurred and their analytical value is limited. Nonetheless, the terms play a fundamental role in the discourse of migration, shaping policies and lives. Therefore, it is important to look more closely at the origins of the distinction and the associated definitions.

During the great age of migration in the last quarter of the nineteenth century to the start of the first world war, there were massive movements of people moved across the world, in particular from Europe and Asia towards the Americas, across the Asia-Pacific and Central Asia regions. Whether people were seeking their fortune in the New World, fleeing violent 
pogroms against minority groups, or trapped in the exploitative, near slavery conditions of bonded labour, they were all seen as migrants, differentiated by race, national origin and class rather than by the level of coercion involved in their movement.

This changed through the first half of the twentieth century as the situation of refugees became a major concern for the emerging international community. First, in response to the chaos in Europe generated by the aftermath of the First World War and the Russian Revolution that left hundreds of thousands of people stateless, the League of Nations created the post of High Commissioner for Refugees in 1921. Its first commissioner, Fridtjof Nansen, introduced a travel document, which came to be known as the Nansen Passport, that enabled refugees to move to countries where they could join family members or find employment to sustain themselves. 'In other words, refugees were to be helped to become migrants: exile and destitution could be solved through continued movement' (Long 2013: 9).

The focus of response changed in the aftermath of the Second World War that created millions of refugees across the continent. This prompted the establishment of the United Nations High Commissioner for Refugees in 1951 (Skran and Daughtry 2007; see also Crawley and Setrana, Chapter 16). While the Nansen passport offered refugees in the interwar period the solution of freedom to move, post-war refugees were offered three durable solutions, all focused on settlement: voluntary repatriation, settlement in the country of first asylum or resettlement in a third country. Refugees were now marked out as a special category of international migrants: those who are outside their country of nationality and unable to return to it or claim protection from it, 'owing to a well-founded fear of being persecuted for reasons of race, religion, nationality, membership of a particular social group or political opinion' (UN 1951). It is worth noting that the emphasis of the definition is not on why people left their country - whether their departure was forced or voluntary - but the reasons for which they cannot return to it.

To a large extent, the emergence of the refugee regime was a product of the Cold War; in the developing world millions of refugees were created by proxy wars driven by the struggle between East and West; in the West, refugees from the East were received as allies against the Soviet threat (Keely 2001). Their geo-political significance helped to ensure that refugees were the primary focus of any discussions about forced migration until the collapse of the Soviet Union in 1991. Others displaced in the upheaval of decolonisation outside the Cold War hotspots - in particular, with Partition in the India sub-continent - were never counted as part of this emerging refugee regime (Chimni 1986). Also those who were forced to move for other reasons, such as earthquakes, floods, drought or other natural disasters had no similar protection under international law. Likewise, those forced to move by conflict or repression but who did not cross international borders - internally displaced persons (IDPs) - remained outside the ambit of the refugee regime. In due course, such considerations 
pushed academics and policy makers to look beyond the narrow focus on refugees (as defined by the UN definition) to the broader field of forced migration.

This shift has been accompanied by vigorous debates. Among academics, some (for example, Hathaway 2007) have argued that refugees are marked out from other forced migrants by their unique position in international law; folding them into the broader category of forced migrants along with IDPs, those displaced by environmental change and others, risks undermining refugee protection. Others (such as DeWind 2007) have taken a more open position, arguing that it is important to understand the interactions between refugees and other forced migrants - and migrants more generally (for a more detailed discussion of these debates, see Bakewell 2011). To a large extent, the latter position has gained more ground. We have moved, then, from the relatively closed field of refugee studies, bound by a legal definition, to the much broader realm of forced migration studies, where the edges are extremely fuzzy.

These academic debates have reflected and influenced major shifts in international policy. This has clearly been seen in the formal adoption of the Guiding Principles on Internal Displacement by the UN in 1998, which, while lacking the legal force of the UN refugee convention, established a set of international norms for states to respond to internal displacement. More recently, there have been active debates about whether and how a similar approach should be adopted to provide protection for those forced to move by climate change (Bettini 2013, Manou et al. 2017; cf. Boas and Wiegel, Chapter 7). The boundaries of forced migration have been further blurred in the policy response to largescale irregular population movements towards wealthy regions of the world, such as the mass movement of Syrians towards Europe in 2015 and the migrant caravans heading towards the US in 2018. The extent to which these populations comprised those fleeing war and political oppression (i.e. refugees), those forced to move by other factors such as impoverishment and environmental degradation, or those who were looking for new opportunities (i.e. economic migrants) has been a subject of great political debate (see Crawley and Skleparis 2018). In the Horn of Africa for example, practitioners, policy makers and some academics have adopted terms such as 'mixed migration' to describe such flows of people (for example, see RMMS 2014). Moreover, rather than simply talk of refugees, with the implication of recognition under international law, they launch programmes to respond to displacement. The description of the $€ 4.5$ billion European Union Emergency Trust Fund for Africa launched in 2015 shows how displacement can be conflated with irregular migration within the same programme:

The European Union Emergency Trust Fund for stability and addressing root causes of irregular migration and displaced persons in Africa (EUTF for Africa) was created to address the root causes of instability, forced displacement and irregular migration and to contribute to better migration management (https://ec.europa.eu/trustfundforafrica/index en accessed 12 December 2019, emphasis added). 
While the world of forced migration has become more complicated since the early days of refugee studies, when we turn to voluntary migration, things are even fuzzier. To a large extent, voluntary migration has been taken as the obverse of forced migration; it is simply all those movements that are not identified as forced. In some of the migration literature, general claims about migration bracket out forced migration; authors seeking to explain why people move take it as self-evident that their theories do not apply to forced migrants (Piguet 2018: 21). While there is a common sense logic to this, it means that there is very little analysis of the areas where even those identified as forced migrants may exercise agency, such as the decision about when to leave, how to move and where to go.

While bracketing out forced migration, some structuralist analyses of migration suggest it is driven by national and global processes, such as capitalist development and globalisation, that leaves people no option but to leave their homes in search of wage employment (for examples, see also Azmeh, Chapter 18; Thibos and Howard, Chapter 12). While individual migrants may see themselves as acting autonomously, they are trapped in a labour migration system that steers them to move in the directions that best serve capital (Delgado Wise and Covarrubias 2008, Piore 1979). From this perspective, it seems perfectly reasonable to describe their migration as forced; however, the nature of the force involved is very different from the explicit threat of immediate violence that drives the movements of many refugees. As a result, few would refer to labour migrants as forced migrants, whatever the structural inequity of the labour market that has given rise to their need to move (a similar discussion surrounds climate change induced migration: Boas and Wiegel, Chapter 7). They may not be forced migrants, but are they voluntary migrants?

This brings us to a question that is all too rarely addressed; when we refer to voluntary migration, how do we define voluntary? Ottonelli and Torresi (2013) tackle this head-on by proposing a set of criteria to assess if a person's migration is voluntary. The most basic condition is that there should be no coercion involved in the migration processes. While many may accept this as enough to demonstrate voluntariness, Ottonelli and Torresi set out three further requirements. First, there must be reasonable alternatives to moving available at home that would enable potential migrants to achieve an adequate quality of life. This means if the alternative is to starve, be exploited or live in conditions where their basic rights are violated, their migration cannot be seen as voluntary. It is also important to recognise that this condition is referring to the area of origin. People move into situations of gross exploitation and rights violations (see examples on migrant exploitation at workplaces and in homes: de Lange, Bernsten and de Sena, Chapter 24; Marchetti, Chapter 25), but this does not render their migration involuntary.

Second, those who migrate must have viable exit options to change the condition of their movement. For example, it must be possible for people to take action such as changing 
employer or deciding to return home at some bearable cost. This condition means that indentured labourers would not be seen as voluntary migrants.

Third, those who move must have adequate information about the journey on which they embark. In particular, they should not be moving at the behest of traffickers who may promise them jobs and then sell them into slavery; neither should they be beguiled by the distorted stories of successful migration that create unrealistic expectations. At the same time, it is important to recognise that whatever information is available, people may exercise an element of self-deception, disregarding risks and over-estimating their likelihood of success (see Thibos and Howard, Chapter 12).

This seems to lay out a reasonable basis for thinking through the voluntary nature of someone's overall decision to migrate. However, it is far from a clearly specified set of criteria that can be readily applied in practice. For example, what actually counts as an adequate alternative option to migration (Bartram 2015)? How do we recognise a reasonable exit option? Perhaps a more telling critique is that this approach focuses on particular elements of the migration process: the decision to leave or the prospects of exit having moved. I may be choosing to move to get a better life with perfectly reasonable expectations of what I may find and no compulsion to stay. However, the structural constraints of law or geography may severely limit the destinations that I can possibly reach, or they may force me to follow very risky routes. The journey itself may impoverish me, leaving me open to exploitation and trapped without the resources to contemplate return. For example, in Morocco, many sub-Saharan African migrants who may have had ambitions to reach Europe find themselves stuck with no option but to settle in Moroccan cities (Berriane et al. 2013). In such ways, voluntary migration can all too easily be transformed into involuntary.

These reflections show that there is an important gap between voluntary and forced migration; they cannot simply be taken as antonyms: that is if migration is not voluntary, it must be forced and vice versa. Most people's migration narratives include some episodes in which they exercise free choices, alongside others where they are forced to take particular actions. Moreover, given that migration is often undertaken by families, different members may perceive things in different ways (Belloni 2019, Hoang 2011); in particular, we need to look carefully at the situationof children, who are obliged to move with their families (see Bonjour and Cleton, Chapter 13).

\section{The importance of the distinction}

As we have seen, it is easy to raise arguments that challenge the idea of there being clear distinctions between forced and voluntary migration. Nonetheless, when it comes to policy and practice, lines are routinely drawn to separate forced from voluntary migrants. Which 
side of the line one falls on can have huge, life-changing, sometimes life-threatening consequences for individual migrants and their families.

In many countries - until recently we might have said particularly Western liberal democracies, but that is changing (see below) - those who are eventually recognised as refugees are granted enhanced rights and support to enable them to settle as part of the legal and humanitarian response to their plight (on the politics of protection see Hart, Chapter 8; Crawley and Setrana, Chapter 16). By contrast, economic migrants may be viewed as a threat to the livelihoods of citizens and may face many barriers to entry, only surmountable by their demonstrating that they will bring a net 'benefit' for their chosen destination (mainly discussed through the concept of skills, cf. Vasey, Chapter 14). How this is assessed is a subject of much debate. Economic analysis may show that migrants create jobs or pay more in taxes than the cost to the host state of providing education, healthcare and other services for their families. A social analysis may focus more on their impact on different parts of the community, educational achievement and so forth (Chapters in Brettell and Hollifield 2015 show these different perspectives).

In other settings, it may be refugees who are seen as the larger threat, especially if they are associated with the violence and insecurity in the country from which they are fleeing. This is more often the case for countries bordering the unstable region; a clear example is the huge concern in Kenya about the presence of Somali refugees. In the Gulf Economic Council countries of the Middle East, there is little acceptance of refugees but the arrival of economic migrants is welcomed as they provide the labour power which is essential for the functioning and growth of the regions' economies (De Bel-Air 2018).

As the discussion in the previous section showed, there are no clear defining characteristics for forced and voluntary migrants. Some of those forced to move may bring with them huge resources; they are not all poor and powerless refugees. Among voluntary migrants, we may include both low-skilled wage labourers and elite 'lifestyle migrants' (Benson and O'Reilly 2009). It is, therefore, important to challenge the stereotypes and generalisations that often pervade the discussions. How far individuals will be identified and/or identify themselves as forced or voluntary migrants and the ensuing consequences will depend on their particular circumstances and the legal, social and political conditions into which they move. In the rest of this section, I focus on three ways in which this may have profound impacts on the lives of migrants: their access to rights; the social and political attitudes that they face; and, their social trajectory as they look to their future.

\section{Access to rights and formal status}

As people move across borders or, in some cases, administrative zones within countries, in in order to enter and settle in these new places, they must establish some form of relationship with the authorities and societies that they encounter there. Their reception may 
depend critically on how they are perceived: in particular, how their motivations for moving are understood. There are ancient roots to the practice of controlling movement in and out of territory, predating the idea of the nation state (for the emergence of modern nation-states and their exclusionary concepts of belonging see Moulin and Rodrigues, Chapter 3; El Qadim, Chapter 19). For example, in fourteenth century England laws were enacted to prevent labourers moving away from the land of their feudal overlords without written authority that stated why they were moving and how long they planned to be away. Sharp distinctions were established between those with legitimate reasons for mobility and vagrants, who may have moved in search of work and failed to find it. The latter, the economic migrants of their day, were subject to harsh punishment and possible return to their masters (Anderson 2013: 13-20). Such practices laid the foundation of the concern of the modern states with its sovereign right to control movement across their borders. And they have always distinguished between migrants on the basis of their reasons for moving. These are echoed in the distinction between voluntary and forced migrants.

While procedures for identifying who should be recognised as a refugee (status determination) vary across the world, they share some common features. First, they examine the conditions under which people left their country, looking for evidence of violence and rights violations - 'a well-founded fear of persecution' - that may have compelled them to leave. Second, once they have determined that a person matches the criteria and they are recognised as a refugee, they gain special rights, usually including the right of entry and always the right not to be returned to their country of origin (the principle of nonrefoulement). The UN Convention relating to the Status of Refugees grants refugees the right to work, own property and freedom of movement within the country of asylum. How far these rights are upheld varies enormously across the world. In many countries of Africa (e.g. Kenya and Tanzania) and Asia (e.g. Thailand and Malaysia), refugees are required to live in designated settlements (camps) and have little or no access to paid employment (Jacobsen and Fratzke 2016: 12-13; cf. Turner, Chapter 23).

Across Europe, North America and Australasia, the rights under the convention may be fully upheld: those who are recognised as refugees are likely to gain preferential access to welfare and public services such as health care, education and housing, compared to other migrants. However, the process of gaining this recognition is tightly controlled and getting ever stricter (see Crawley and Setrana, Chapter 16). Some countries have other categories that may provide some similar but lesser protection for those who are seen as only partially meeting the criteria for refugee status. This is not the place to elaborate on these different approaches (Carmel and Paul 2013 provide a more detailed analysis of the variations across European states). The critical point here is that if one's migration is formally recognised as 'forced', it brings special rights and privileged access to resources. 
Apart from these processes of formal status determination, those identified as forced migrants are frequently the targets of aid interventions in response to the particular hardships they face. This is likely to cover a much broader set of forced migrants than the refugees and asylum seekers recognised by states. In particular, it includes internally displaced persons (IDPs), a category of forced migrant whose numbers across the world far exceed the number of refugees (40 million IDPs compared to 25 million refugees in 2019 $\mathrm{UNHCR}^{1}$ ). It may also include those displaced by other disasters, such as drought, floods, earthquakes, rather than the violent conflict and persecution associated with refugee status.

Depending on the contexts, these aid interventions may include meeting basic needs for food, water, shelter and healthcare; supporting people into jobs or other income generation activities; education and training especially in languages; psychosocial support to address the trauma of displacement; legal advice and support to help people secure their rights. The range of issues addressed will vary enormously across the world and even spaces within countries such as camps vs urban settings (see e.g. Turner, Chapter 23). In many developing countries, they may be more focused on basic needs; in most OECD countries, the state is more likely to cover basic needs and aid interventions tend to offer supplementary support, such as language training or legal services. This may be offered by UN and international organisations (such as UNHCR or ICRC), local, national and international nongovernmental organisations (NGOs), faith groups (such as the Catholic Church, local mosques) and other civil society organisations. Whatever the type or source of the support, it is only provided to those who can show that they are forced migrants according to the criteria set by the organisation concerned.

Of course, there may be a significant gap between the lived experience of moving with all the confusion and messiness discussed above, and the clear narrative presented to 'prove' that the migration is forced. The mechanisms for determining who should be recognised as a forced migrant are usually built on a set of stereotypical assumptions about how a forced migrant should behave and suspicions about the credibility of their story of their migration (Sigona 2014). For migrants, who fail to perform according to the required script of victimcy (O'Higgins 2012, Utas 2005) and whose case is rejected, the consequences can be dire: potentially deportation, destitution, and even death. Moreover, the maze of legal definitions and bureaucratic rules that delineate between different categories of migrants can present an incredibly complex set of pathways for migrants to navigate. As their lives unfold in ways that do not fit with the patterns envisaged in legislation, their decisions about how and when to describe their experiences to the authorities can have unforeseen legal consequences, shaping whether they are granted refugee status, some form of subsidiary protection or are classified as economic migrants (Carmel and Paul 2013; see also Mofette, Chapter 28).

\footnotetext{
${ }^{1}$ www.unhcr.org/globaltrends2018
} 


\section{Social and political attitudes}

So far, we have only referred to the significance of securing recognition as a forced migrant. While there is no equivalent legal, administrative or aid category associated with voluntary migration, in popular discourse, those whose migration is deemed not to be forced are widely perceived as voluntary migrants - often using terms such as economic migrants. In the eyes of many, while forced migrants deserve help and protection, those who have chosen to move must take responsibility for their own fate. If they are thought to have tried to cheat the system, by trying and failing to claim rights or benefits as a forced migrant, they may face public hostility. This bifurcation in response and attitudes between 'refugees' and 'economic migrants' is seen very clearly in many parts of Europe as significant numbers of migrants from poor and conflict-affected areas use irregular routes to cross borders. While refugees may be accepted, those identified as economic migrants are often vilified by hostile media and sections of the public, accused of criminality, stealing jobs, and draining social welfare. However, the acceptance of forced migrants itself has its limits, as was demonstrated by the hostile response from some sections of the German public to the country's admission of relatively large numbers of Syrian refugees in $2015^{2}$ (see Borneman and Ghassem-Fachandi 2017).

There are very different attitudes towards those most voluntary of migrants - the wealthy, well-educated elites, who freely move around the world to take up 'high-skilled' jobs or establish businesses (Favell 2008). While poor unskilled migrants face increasing barriers to entry and widespread hostility, the 'best and brightest' are the subject of a global competition for their talents (Kapur and McHale 2005; see also Vasey, Chapter 14). Because they are free to move, there is enormous pressure on states from businesses and universities, among others, to ensure that they can make it easy for such migrants to enter the country and to settle there. As a result, across the world, there has been an overall reduction in visa restrictions for these 'desirable' migrants, while restrictions have increased to deter the 'undesirable' poor voluntary migrants (de Haas, Natter and Vezzoli 2016). As a growing body of research is demonstrating, while these approaches are often presented as neutral and technical ways of recognising skills and granting rights of admission and settlement, in practice they serve to reinforce longstanding structures of inequality based on race, gender, religion and class (Ellermann 2019; see also Mayblin, Chapter 2).

While being recognised as a forced migrant may elicit more sympathy and acceptance in some settings, in others, particularly in developing countries, it is associated with poverty and shame. Across most of Africa and many countries in Asia, the responses to refugees and IDPs are focused around camps (Bakewell 2014). They may face restrictions on their

\footnotetext{
${ }^{2}$ This hostility shifted into the mainstream and took on exacerbated racial and gendered tones after the sexual assaults in Cologne on New Year's Eve, which resulted in the portrayal of Syrian male refugees as a racialised threat to German women.
} 
movements outside the camp, have special identity cards that mark them out, or be associated with the violence of the conflict they have fled. Moreover, there is a widespread discourse of refugees as a burden on the hosting state and society (Kreibaum 2016). Hence, we find that some people who have fled violence and meet the criteria for recognition as refugees or IDPs may try avoid being categorised in this way. For example, few Iraqis in Jordan seek recognition from UNHCR as they see the costs outweighing the benefits (Chatelard 2010). In Somalia, those who have more resources when they were displaced were able to settle in the cities to which they fled rather than joining the mass of IDPs who were housed in special camps on the edge of town (EUTF-REF 2018: 40).

So far, this discussion has highlighted how the distinction between forced and voluntary migration affects social attitudes. However, where xenophobic attitudes prevail and there is violent hostility towards foreigners in general or towards a particular national group (cf. Guia, Chapter 33), the mob makes no such distinction: forced and voluntary are equally targeted. This can be clearly seen in South Africa, where thousands of Somalis and Zimbabweans have suffered xenophobic attacks on their homes and businesses regardless of whether they moved as economic migrants or seeking refuge from the political violence in their countries of origin (Crush et al. 2015)

\section{Social trajectory}

Being recognised as a forced migrant may bring benefits - access to rights and resources that are critically important in the short-term, but over time, the category may become something of a trap. For example, across much of Africa, refugees face larger obstacles to gaining citizenship than other migrants (Manby 2016); in some countries, such as Uganda and Zambia there is no effective pathway to citizenship for refugees (Bakewell 2018, Hovil and Lomo 2015: 46). As a result, they may be seen as temporary visitors who are provided with asylum until they are able to return to their country. However, in many cases the conflicts have continued over many years, so those identified as refugees or IDPs - and often their children born in exile - are caught in limbo, unable to go 'home' or to make the place where they live a new home (Aleinikoff 2015, Brun and Fábos 2015).

As a result, being marked out as a forced migrant can have profound impacts on people's ideas for the future (on insecurities of status stretching through time see Griffiths, Chapter 26). Research among IDPs in Colombia has shown how the experience of displacement has long-reaching impacts on people's social and cognitive landscapes, creating enduring social boundaries between the displaced and their non-displaced neighbours and profound difficulties in establishing a sense of home (Celestina 2018, Perez Murcia 2019).

In wealthier parts of the world, where the numbers of refugees are much smaller, those who are granted asylum have often been able to move forward to citizenship, bringing to an end their refugee status and enabling them to settle in the same ways as any other immigrants. 
This is changing as states introduce more temporary statuses with fewer rights, including more restricted access to citizenship. For example, Germany established three different humanitarian admission schemes for Syrians, which, while seeming generous in allowing people to enter the country, offered fewer rights than those available to convention refugees (Tometten 2018). This legal uncertainty is overlaid with increasingly hostile public discourse that represents refugees and asylum seekers as a threat to national identity, the economy and security (Holzberg, Kolbe and Zaborowski 2018, Pruitt 2019; cf. Guia, Chapter 33). This creates huge insecurity for forced migrants and makes their pathway to settlement much harder to follow.

\section{Challenging the distinction}

As we have seen, there are no sharp lines between forced and voluntary migration in terms of people's experiences. At the same time, these categories play a very important role in policy and practice and have a huge impact on people's lives. While it is easy to denounce the simplistic and inappropriate response of the states that do not recognise the complexity of people's stories, it is much harder to give a constructive alternative (short of the argument for open borders) that ensures the principle of humanitarian protection. There is perhaps a discussion to be had about whether those principles (as they are currently worked out) are worth the injustices that they create. My inclination would be to stick with the principles and refine and improve how they are put into practice. If humanitarian protection is to have any value, it has to have boundaries that define who is to be protected. However, these need to be transparent and consistent rather than open to capricious change at the unchallenged whim of political expediency. As things stand, we seem to be a long way from this position. Too often people are trapped in categories of forced and voluntary migration that are a reflection of where, when and how a state, NGOs or other actor determined their eligibility. This creates huge inconsistencies in migrants' access to rights and support across the world.

As scholars engage in the challenge of seeking better approaches, they need to be very cautious about using forced and voluntary migration as categories of analysis (Bakewell 2008). The fact that a set of individuals has been formally identified as forced (or voluntary) migrants does not tell us much about their different experiences or characteristics. As we have seen above, these may vary widely and we cannot assume that refugees share distinctive qualities that mark them out (for example in terms of background, wealth or skills) simply because they are refugees. These are grounds to question critically the value of any idea of the 'refugee community' or the 'refugee experience'.

Alongside questioning of the categories, it is also important to challenge the way that the forced and voluntary migration are often analysed using separate theories. Given the mix of motivations and patterns of movements that underpin any migration, whether it is seen as forced or voluntary (as outlined above), it is important to look both at the conditions that 
may have forced the voluntary migrant to move, and the choices made by the forced migrant.

It is important to find a balance here. If too much agency is ascribed to forced migrants, this may be taken as grounds to negate their rights to asylum. However, failing to recognise people's agency means that we deny their autonomy - obscuring their choices and strategies and presenting them as victims (on victimisation, see also Thibos and Howard, Chapter 12). At the same time, we have to learn better to listen to the voices of migrants as we seek that balance. While we do not all share the personal experience of migration, each of us perhaps share the assumption that we can make decisions for our own lives, albeit recognising the structural conditions shaping our choices, and expect these decisions to be respected. It should not be hard to extend the same outlook to many migrants, rather than assume that their decisions must have been forced upon them.

\section{References}

Aidani, Mammad. 2010. "Existential Accounts of Iranian Displacement and the Cultural Meanings of Categories." Journal of Intercultural Studies 31(2):121-43. doi: 10.1080/07256860903579061.

Aleinikoff, T. Alexander. 2015. "From Dependence to Self-Reliance: Changing the Paradigm in Protracted Refugee Situations." Vol. Washington D.C.: Migration Policy Institute.

Anderson, Bridget. 2013. Us and Them?: The Dangerous Politics of Immigration Control. Oxford: Oxford University Press.

Bakewell, Oliver. 2008. "Research Beyond the Categories: The Importance of Policy Irrelevant Research into Forced Migration." Journal of Refugee Studies 21(4):432-53.

Bakewell, Oliver. 2011. "Conceptualising Displacement and Migration: Processes, Conditions, and Categories." Pp. 14-28 in The Migration-Displacement Nexus: Patterns, Processes, and Policies, Forced Migration, edited by K. Koser and S. Martin. Oxford: Berghahn Books.

Bakewell, Oliver. 2014. "Encampment and Self-Settlement." Pp. 127-38 in The Oxford Handbook of Refugee and Forced Migration Studies, edited by E. Fiddian-Qasmiyeh, G. Loescher, K. Long and N. Sigona. Oxford: Oxford University Press.

Bakewell, Oliver. 2018. "Negotiating a Space of Belonging: A Case Study from the ZambiaAngolan Borderlands." Pp. 103-26 in Forging African Communities: Mobility, Integration and Belonging, edited by O. Bakewell and L. B. Landau. London: Palgrave.

Bartram, David. 2015. "Forced Migration and "Rejected Alternatives": A conceptual Refinement." Journal of Immigrant \& Refugee Studies 13(4):439-56. doi: 10.1080/15562948.2015.1030489. 
Belloni, Milena. 2019. "Family Project or Individual Choice? Exploring Agency in Young Eritreans' Migration." Journal of Ethnic and Migration Studies:1-18. doi: 10.1080/1369183X.2019.1584698.

Benson, Michaela and Karen O'Reilly. 2009. "Migration and the Search for a Better Way of Life: A Critical Exploration of Lifestyle Migration." The Sociological Review 57(4):60825. doi: 10.1111/j.1467-954X.2009.01864.x.

Berriane, Mohamed, Mohammed Aderghal, Mhamed Idrissi Janati and Johara Berriane. 2013. "Immigration to Fes: The Meaning of the New Dynamics of the Euro-African Migratory System." Journal of Intercultural Studies 34(5):486-502. doi: 10.1080/07256868.2013.827825.

Bettini, Giovanni. 2013. "Climate Barbarians at the Gate? A Critique of Apocalyptic Narratives on 'Climate Refugees'." Geoforum 45:63-72. doi: http://dx.doi.org/10.1016/j.geoforum.2012.09.009.

Borneman, John and Parvis Ghassem-Fachandi. 2017. "The Concept of Stimmung: From Indifference to Xenophobia in Germany's Refugee Crisis." HAU: Journal of Ethnographic Theory 7(3):105-35. doi: 10.14318/hau7.3.006.

Brettell, Caroline, and James Frank Hollifield, eds. 2015. Migration theory: talking across disciplines. 3rd ed. New York and London: Routledge.

Brun, Cathrine and Anita Fábos. 2015. "Making Homes in Limbo? A Conceptual Framework." Refuge: Canada's Journal on Refugees 31(1).

Carmel, Emma and Regine Paul. 2013. "Complex Stratifcation: Understanding European Union Governance of Migrant Rights." Regions \& Cohesion 3(3):56-85.

Celestina, Mateja. 2018. Living Displacement: The Loss and Making of Place in Colombia. Manchester: Manchester University Press.

Chatelard, Geraldine. 2010. "What Visibility Conceals: Re-Embedding Refugee Migration from Iraq." Pp. 17-44 in Dispossession and Displacement: Forced Migration in the Middle East and North Africa, edited by D. Chatty and B. Finlayson. Oxford: Oxford University Press.

Chimni, B.S. 1998. "The Geopolitics of Refugee Studies: A View from the South." Journal of Refugee Studies 11(4):350-374.

Crawley, Heaven and Dimitris Skleparis. 2018. "Refugees, Migrants, Neither, Both: Categorical Fetishism and the Politics of Bounding in Europe's 'Migration Crisis'." Journal of Ethnic and Migration Studies:1-17. doi: 10.1080/1369183X.2017.1348224.

Crush, Jonathan, Abel Chikanda, and Caroline Skinner. 2015. Mean Streets: Migration, Xenophobia and Informality in South Africa. Rondebosch: Southern African Migration Programme, African Centre for Cities and the International Development Research Centre. 
De Bel-Air, Françoise 2018. "Policies and Politics in the Arab Migration to the Gulf States: Struggling to Keep the Door Open." In Migration to the Gulf: Policies in Sending and Receiving Countries, edited by Philippe Fargues and Nasra M. Shah, 151-177. Cambridge: Gulf Research Centre.

de Haas, Hein, Katharina Natter and Simona Vezzoli. 2016. "Growing Restrictiveness or Changing Selection? The Nature and Evolution of Migration Policies." International Migration Review 52(2):324-67. doi: 10.1111/imre.12288.

Delgado Wise, Raúl and Humberto Márquez Covarrubias. 2008. "Capitalist Restructuring, Development and Labour Migration: The Mexico-Us Case." Third World Quarterly 29(7):1359-74. doi: 10.1080/01436590802386542.

DeWind, Josh. 2007. "Response to Hathaway." Journal of Refugee Studies 20(3):381-85. doi: 10.1093/jrs/fem022.

Ellermann, Antje. 2019. "Discrimination in Migration and Citizenship." Journal of Ethnic and Migration Studies:1-17. doi: 10.1080/1369183X.2018.1561053.

EUTF-REF. 2018. "Return and (Re)Integration after Displacement: Belonging, Labelling and Livelihoods in Three Somali Cities." Vol. London and Nairobi: EU Trust Fund for Africa (Horn of Africa Window) Research and Evidence Facility.

Favell, Adrian. 2008. Eurostars and Eurocities: Free Movement and Mobility in an Integrating Europe. Oxford: Blackwell.

Hathaway, James C. 2007. "Forced Migration Studies: Could We Agree Just to 'Date'?". Journal of Refugee Studies 20(3):349-69. doi: 10.1093/jrs/fem019.

Hoang, Lan Anh. 2011. "Gender Identity and Agency in Migration Decision-Making: Evidence from Vietnam." Journal of Ethnic and Migration Studies 37(9):1441-57. doi: 10.1080/1369183X.2011.623618.

Holzberg, Billy, Kristina Kolbe and Rafal Zaborowski. 2018. "Figures of Crisis: The Delineation of (Un)Deserving Refugees in the German Media." Sociology 52(3):534-50. doi: $10.1177 / 0038038518759460$.

Hovil, Lucy and Zachary A. Lomo. 2015. "Forced Displacement and the Crisis of Citizenship in Africa's Great Lakes Region: Rethinking Refugee Protection and Durable Solutions." Refuge: Canada's Journal on Refugees 31(2).

Jacobsen, Karen and Susan Fratzke. 2016. "Building Livelihood Opportunities for Refugee Populations: Lessons from Past Practice." Vol. Washington D.C.: Migration Policy Institute.

Kapur, Devesh and John McHale. 2005. Give Us Your Best and Brightest: The Global Hunt for Talent and Its Impact on the Developing World. New York: Center for Global Development. 
Keely, Charles B. 2001. "The International Refugee Regime(S): The End of the Cold War Matters." The International Migration Review 35(1):303-14.

Kreibaum, Merle. 2016. "Their Suffering, Our Burden? How Congolese Refugees Affect the Ugandan Population." World Development 78:262-87. doi:

https://doi.org/10.1016/j.worlddev.2015.10.019.

Long, Katy. 2013. "When Refugees Stopped Being Migrants: Movement, Labour and Humanitarian Protection." Migration Studies 1(1):4-26. doi: 10.1093/migration/mns001.

Manby, Bronwen. 2016. Citizenship Law in Africa: A Comparative Study. New York, NY: Africa Governance Monitoring and Advocacy Project, Open Society Justice Initiative, Open Society Institute.

Manou, Dimitra, Andrew Baldwin, Dug Cubie, Anja Mihr and Teresa Thorp, eds. 2017. Climate Change, Migration and Human Rights: Law and Policy Perspectives. London: Routledge. (https://www.taylorfrancis.com/books/e/9781315622217).

O'Higgins, Aoife. 2012. "Vulnerability and Agency: Beyond an Irreconcilable Dichotomy for Social Service Providers Working with Young Refugees in the Uk." New Directions for Child and Adolescent Development 2012(136):79-91. doi: 10.1002/cad.20012.

Ottonelli, Valeria and Tiziana Torresi. 2013. "When Is Migration Voluntary?". International Migration Review 47(4):783-813. doi: 10.1111/imre.12048.

Perez Murcia, Luis Eduardo. 2019. "'The Sweet Memories of Home Have Gone': Displaced People Searching for Home in a Liminal Space." Journal of Ethnic and Migration Studies 45(9):1515-31. doi: 10.1080/1369183X.2018.1491299.

Piguet, Etienne. 2018. "Theories of Voluntary and Forced Migration." Pp. 17-28 in Routledge Handbook of Environmental Displacement and Migration, edited by R. McLeman and F. Gemenne. Abingdon: Routledge.

Piore, Michael J. 1979. Birds of Passage: Migrant Labor and Industrial Societies. Cambridge: Cambridge University Press.

Pruitt, Lesley J. 2019. "Closed Due to 'Flooding'? Uk Media Representations of Refugees and Migrants in 2015-2016 - Creating a Crisis of Borders." The British Journal of Politics and International Relations 21(2):383-402. doi: 10.1177/1369148119830592.

RMMS. 2014. Going west: contemporary mixed migration trends from the Horn of Africa to Libya $\mathcal{E}$ Europe. Mixed migration research series, Explaining people on the move - paper 5. Nairobi: Regional Mixed Migration Secretariat. http://www.mixedmigration.org/wpcontent/uploads/2018/05/008 going-west.pdf

Sigona, Nando. 2014. "The Politics of Refugee Voices: Representations, Narratives, and Memories." Pp. 369-82 in The Oxford Handbook of Refugee and Forced Migration Studies, edited by E. Fiddian-Qasmiyeh, G. Loescher, K. Long and N. Sigona. Oxford: Oxford University Press. 
Skran, Claudena and Carla N. Daughtry. 2007. "The Study of Refugees before "Refugee Studies"." Refugee Survey Quarterly 26(3):15-35. doi: 10.1093/rsq/hdi0240.

Tometten, Christoph. 2018. "Resettlement, Humanitarian Admission, and Family Reunion: The Intricacies of Germany's Legal Entry Regimes for Syrian Refugees." Refugee Survey Quarterly 37(2):187-203. doi: 10.1093/rsq/hdy002.

Utas, Mats. 2005. "West-African Warscapes: Victimcy, Girlfriending, Soldiering: Tactic Agency in a Young Woman's Social Navigation of the Liberian War Zone." Anthropological Quarterly 78(2):403-30. 